\title{
Towards a high-performance HR bundle process for lean service operations.
}

\author{
Araz Zirar
}

Huddersfield Business School, University of Huddersfield

Clive Trusson

School of Business and Economics, Loughborough University

Alok Choudhary

School of Business and Economics, Loughborough University

Accepted for publication in International Journal of Quality and Reliability Management $20^{\text {th }}$ January, 2020

DOI: 10.1108/IJQRM-10-2019-0330

\section{Abstract}

Purpose - This article presents an empirically-induced 'high performance' 'Human Resources (HR) bundle', comprising six HR practices, for supporting lean service operations.

Design/methodology/approach - A multiple case study. A qualitative dataset, including transcripts from 27 semi-structured in-depth interviews with lean practitioners from across five service organizations that have adopted lean practices, was thematically analysed to establish key HR practices on the road to lean maturity.

Findings - A 'high performance' HR bundle of three work practices and three employment practices emerged from the analysis. These practices typically mature implicitly rather than systematically to support organizations in successfully implementing lean service operations, by: resourcing the most suitable people for carefully-defined roles; providing workers with extensive lean training opportunities; 
appraising workers' performances such that lean-behaviours are recognized and rewarded; and encouraging a participative teamworking culture.

Research limitations/implications - This article uses cross-sectional data from five case studies to induce a 'high performance' 'HR bundle' theoretical model and process. A larger number of case studies and/or longitudinal data would add credence.

Practical implications - Lean service managers should regard HR practices as integral to the lean maturation process and might usefully conceive of them as processes allowing for greater management control to achieve incremental improvements to lean service provision.

Originality/value - The article provides deeper understanding of the importance of HR practice for lean service organizations and offers practical suggestions for managing HR practices in this context.

Keywords: HPWS, HR Bundle, HR Strategy, Lean Management, Lean Service, Teams.

\section{Introduction}

Having originated in the manufacturing sector, lean practices have increasingly been adopted to improve service provision thus creating better value for customers (Bowen and Youngdahl, 1998). It has been argued that the application of lean principles to services improves service quality and productivity, reduces service delivery timeframes, and facilitates innovation (Lorden et al., 2014; Lindskog et al., 2017). However, studies also suggest that it is not enough to simply apply lean tools and techniques. Unless working practices are redesigned and training invested in to achieve commitment to the underpinning lean philosophy, lean initiatives may fail to deliver anticipated benefits (Sparrow et al., 2014; Sony et al., 2018; Antony et al., 2019). This study draws on 'real 
world' qualitative data to illustrate how human resources (HR) practices, and specifically those associated with high performance work systems (HPWS) theory, have been implemented as a feature of lean service provision and matured alongside the lean service operational processes. As such it is argued that it may be useful, for control, to perceive these HPWS HR practices in process terms that might be continuously monitored and improved.

HPWS theory established itself as a rhetorical feature of the 'best practice' school of Strategic Human Resource Management (SHRM) that holds that the way workers are managed affects organizational performance levels and that there are common elements of management practice that might be usefully standardized and/or learned and transferred across organizations to improve productivity (Huselid, 1995; Pfeffer, 1998; Sundbo, 2002; Weiss, 2000). The key idea of the HPWS is that, to improve employee effectiveness and thereby optimize organizational performance, a set (or 'bundle') of specific HR practices should be identified for considered managerial control (Gittell et $a l ., 2010$ ). Given that "HPWSs depend on positive responses from employees" (Boxall and Macky, 2009, p. 6) and the applicability of HR 'best practices' to service organizations (Browning et al., 2009), managers of service organizations who strategically embrace lean principles should particularly consider how they ensure their employees are positively inclined towards adopting lean practices.

There is a dearth of qualitative research that might suggest what practices should feature prominently within an HR bundle for service organizations implementing lean. This article speaks into that gap in the literature and, by drawing on data from a multiple case study, proposes: (i) how HR 'best practices' might be formulated as a bundle of 
interrelated management-controlled processes, and (ii) how that HR bundle might itself be managed as a process.

This article reports on multiple case studies of service organizations who have implemented lean. This approach has facilitated the generation of a theoretical, evidence-based formulation of a 'best practice' high-performance HR bundle to function symbiotically with lean service operations. The article proceeds with two contextualising literature review sections. The first of these discusses literature related to the adoption of lean in the service sector. This is followed by a discussion of the relationship between lean and the HR bundle. This latter section concludes by stating our research question and leads on to a section detailing the research methods employed for this multiple case study. After reporting the findings of the study, a discussion section proposes as a contribution to the literature a high-performance 'best practice' HR bundle process for use by lean service providers to achieve incremental service improvement when enacted as part of a lean initiative. This is followed by a brief conclusion to the article.

\section{Lean in the Service Context}

'Lean', conceived as a practical set of management practices geared towards more efficient production, was initiated in the manufacturing sector and later adopted for the service sector (Krafcik, 1988; Womack and Jones, 1996; Bowen and Youngdahl, 1998). Rooted in the scientific management principles of F.W. Taylor (1911), lean has borrowed from various management disciplines (Holweg, 2007) to offer a rational approach to continually improve organizational efficiency. Pertinent to this study, Shah et al. (2008, p. 6683) point to lean being 'a bottom up approach where management 
plays a supportive and facilitating role in engaging shop-floor workers to form crossfunctional self-directed work teams and apply lean tools.' Thus, management of the workforce is vital for successfully adopting lean practices.

The emergent literature on lean service provision has reported multiple benefits. For example, lean approaches to financial services provision have resulted in faster service delivery and increased service capacity (Delgado et al., 2010; Vashishth et al., 2017); and in IT services led to improved operational performance and service quality, and reduced rework (Malladi et al., 2011; Staats et al., 2011). This literature has emphasized two directional drivers for lean service providers: a 'market driver' and an 'efficiency driver'(Radnor and Johnston, 2013). The 'market driver' directs organizations towards creating value for customers, whereas, the 'efficiency driver' ensures a systems-thinking focus on improving service delivery processes. This bifocal emphasis on 'customers' and 'processes' has implicitly diminished the importance of applying focus on the workforce. Rather, from the lean perspective, workers are rationalized as interchangeable system 'resources' who support the 'processes' that provide value to 'customers'.

It might be noted here that critical management perspectives on lean methods highlight that lean objectives of efficiency and improvement tend to be defined in terms of cost reduction. As such, lean management inevitably entails a continuous search for marginal cost-reducing improvements 'by stressing and readjusting the production system and, above all, the labor process' (Moody, 1997, p. 87). Thus, lean rhetoric that emphasizes work enrichment might be juxtaposed with 'lean' cost-reduction techniques of workforce casualization, work intensification and deskilling, and the capture and redistribution of worker knowledge to facilitate downgrading of work or outsourcing to 
cheaper labour resources (Moody, 1997; Vidal and Hauptmeier, 2014). It might be suggested that a crude concern for minimising the cost of labour may undermine performance-enhancing objectives of applying focus to 'the very humanness of this resource' through HR practices of empowerment that have been associated with high performing organizations (Appelbaum et al., 2000; Gratton, 2000, p. 3). In short, an over-emphasis on rationalized 'resource' efficiency may risk undermining the 'human' contribution to contextualized service effectiveness.

In this article we remain true to lean methodological principles by proposing that the lean 'efficiency driver' mindset might be usefully applied to the HR bundle and its underlying practices, re-conceptualising them as processes that might be placed under management control for continuous improvement (i.e. managed maturation).

\section{Lean and the HR Bundle}

An organization implementing a lean service strategy should, in addition to applying lean tools and techniques, revise working practices and ensure workforce commitment to lean ways of working and strategic objectives ( Holbeche, 1998; Sparrow and OtayeEbede, 2014). Therefore, managers of organizations adopting lean need to give thoughtful attention to HR practices. The adoption of the concept of the HR bundle is long-established in the lean literature (Liker and Meier, 2007) borrowing the term from the strategic HRM (including HPWS) literature (Huselid, 1995). There is an assumption within such thinking that organizational performance might be enhanced by controlling an interacting set of specific work practices acting collectively as a sub-system. So, the practices can be controlled individually but as a 'bundle' they operate systemically, "shaping the pattern of interactions between and among managers and employees" 
(MacDuffie, 1995, p. 200), to support the fulfilment of business objectives (Holbeche, 1999) and achieve operational productivity and efficiency gains (Delery and Gupta, 2016). Thus, as Boxall and Macky $(2009$, p. 5) note, "there are systemic or synergistic effects in the cluster of chosen HR practices."

The broader research literature points to there being significant ambiguity about the bundle of HR practices (e.g. recruitment, reward, training, etc.) that is pertinent for a HPWS generally (Gittell et al., 2010) and a HPWS supportive of lean service operations specifically (de Koeijer et al., 2014). There are also different perspectives on how those practices might be applied by managers across different organizational settings.

Previous studies, mainly conducted in manufacturing environments, have focused on 'what' HR practices are most relevant when adopting lean principles (MacDuffie, 1995; Shah and Ward, 2003). Within HPWS theory the concept of the 'HR bundle' is used to denote a specific set of HR practices with an assumption that these practices combine to '[create] a performance advantage for organizations' (Gittell et al., 2010, p. 491). These individual HR practices might usefully be considered as either primarily 'work practices' that relate to how operational work is structured and organized (e.g. teamworking arrangements), or primarily 'employment practices' that relate to processdriven management-employee interactions (e.g. performance appraisal) (Boxall and Macky, 2009).

In the lean theory models proposed by Shah and Ward (2003) and Dal Pont et al., (2008) the 'HR' bundle sits alongside two other theoretically interconnected 'bundles': the 'Total Quality Management' (TQM) bundle and the 'Just-in-Time' (JIT) bundle. The lean discourse conforms with dominant approaches to HRM that consider it a mechanism for affecting employees' attitudes and behaviours to improve organizational 
performance and enhance competitiveness (De Saá Pérez and García Falcón, 2004;

Browning et al., 2009). That is, HRM is part of an organizational strategic logic to ‘manage' workers as commodified 'resources' (De Saá Pérez and García Falcón, 2004) towards commitment to and involvement in the organizational performance effort.

Further, there is no considered intent to enhance employee wellbeing for ethical reasons (Guest, 2017) and indeed such approaches may imply 'harsh realities' for employees, because lean logic may lead to work intensification and 'leaner staffing' (Pfeffer, 1998; Marchington and Grugalis, 2000, p. 409).

However, the literature on the HR bundle within lean service contexts remains underdeveloped. Given the people-centric nature of service provision, consideration of the HR bundle is assumed to be of particular concern via-à-vis manufacturing contexts. There is also a lack of unanimity about which HR practices should be included within the lean HR bundle. Analysis of the literature points to the significance of five particular HR practices for supporting lean operations. Three of these are work practices (HR planning, teamworking, and employee participation/involvement), and two are employment practices (training, and reward) (Table 1).

Table 1: Studies reporting on the Lean HR bundle showing common HPWS practices.

\begin{tabular}{|c|c|c|c|c|c|}
\hline \multirow[b]{3}{*}{ Authors } & \multicolumn{5}{|c|}{ HR Practices } \\
\hline & \multicolumn{3}{|c|}{ Work Practices } & \multicolumn{2}{|c|}{ Employment Practices } \\
\hline & $\begin{array}{l}\text { HR } \\
\text { Planning }\end{array}$ & $\begin{array}{l}\text { Team } \\
\text { working }\end{array}$ & $\begin{array}{l}\text { Employee } \\
\text { Participation }\end{array}$ & Training & Reward \\
\hline MacDuffie (1995) & & & & $\bullet$ & $\bullet$ \\
\hline Panizzolo (1998) & & $\bullet$ & $\bullet$ & $\bullet$ & $\bullet$ \\
\hline Power \& Sohal (2000) & & $\bullet$ & $\bullet$ & $\bullet$ & \\
\hline Shah \& Ward (2003) & $\bullet$ & $\bullet$ & & & \\
\hline Dal Pont et al. (2008) & & $\bullet$ & $\bullet$ & $\bullet$ & \\
\hline Bonavia \& Marin-Garcia (2011) & & & & $\bullet$ & $\bullet$ \\
\hline Martĭnez-Jurado et al. (2013) & $\bullet$ & $\bullet$ & & $\bullet$ & $\bullet$ \\
\hline de Koeijer et al. (2014) & $\bullet$ & $\bullet$ & & $\bullet$ & $\bullet$ \\
\hline Mostafa et al. (2015) & & $\bullet$ & $\bullet$ & $\bullet$ & \\
\hline Netland et al. (2015) & $\bullet$ & $\bullet$ & & & \\
\hline
\end{tabular}


This literature suggests an ambiguity concerning the relative importance of HR practices (Bello-Pintado, 2015). In practical terms, the composition of a lean HR bundle and the various emphases applied to HR practices will be contingent upon organizational context. However, there is a lack of case study research to provide contextual and real-world understanding of how HR practices are implemented in support of lean services. Thus, the multiple case studies approach of this research seeks to address the following guiding research question:

'How are service organizations employing HR practices (comprising work practices and employment practices) to support their lean operations?'

This article contributes to the literature by reporting on specific HR practices as implemented at five service providing organizations that had confirmed that they had implemented lean to various stages of lean maturity.

\section{Research Methods}

A multiple case studies approach was adopted for this study, allowing for an exploration of the research domain in its 'real-world' context (Voss et al., 2016). The main research question acted as a directional device for exploring the phenomenon of HR practices employed to support lean service. The intention was to draw on qualitative data in order to develop understanding of the relationships between HR practices and organizational lean service performance, and in doing so generate a theoretical 'best practice' HR bundle that others might test in the field (Bryman, 2001; Harley, 2015). 
Qualitative data were collected from within five case study service-providing organizations to provide a dataset of practitioner perspectives on HR-enabled lean services. As such, multiple perspectives were considered through the generation of a multi-faceted dataset (Gray, 2016). Case study research is highly effective in this kind of research endeavour by integrating similar and contrasting perspectives to build a rich and detailed understanding of the phenomenon in a specific context (Yin, 2009). The multiple case studies approach strengthens claims to analytical generalization (Gomm et al., 2000).

The criteria for selecting organizations were that they provided services and their management asserted claims to have gained competitively from applying lean principles to their service operations. Three selected companies operated in the financial services sector (MyFinance, FineBank, Hinance), one provided waste management and recycling services (EastManage), and one provided food distribution services (HighEnd). Twentyseven interviews were conducted across the five organizations, with interview participants being selected on the criteria that they were involved in and had management responsibilities relating to lean service provision (i.e. were lean practitioners) (Table 2). The authors hold with the consensus view that there is no definitive number of interviews required for a qualitative study but 'you keep asking as long as you are getting different answers' (Baker and Edwards, 2012, p. 4). This approach of getting to a point of theoretical saturation (Glaser and Strauss, 1967) inevitably entails formative data analysis while still collecting data. On completion of 27 interviews with lean practitioners it was considered that the data collected and formatively analysed had reached a point where it was appropriate to move to formal coding of the data using NVivo 10 software. We draw support for this position that ensures that 'conclusions [do not go] beyond what the data can support' from the 
guidance provided by the noted sociologist Howard S. Becker (in Baker and Edwards, 2012, p. 15). The interview data were coded following the four stages of using NVivo to analyse qualitative data outlined by Bazeley and Jackson (2013). Rigorous thematic analysis was conducted with reference to Braun and Clark's (2013) six-stage approach to theme generation from the codes and 15-point checklist for 'good' thematic analysis.

Table 2: Case study organisations and participants' position of responsibility.

\begin{tabular}{|c|c|c|}
\hline Organisation & Service Activities & Interviewed Lean Practitioners' Job Titles \\
\hline HighEnd & $\begin{array}{l}\text { Food distribution centre } \\
\text { servicing c. } 500 \text { stores. }\end{array}$ & $\begin{array}{ll}\text { - } & \text { Distribution General Manager } \\
\text { - } & \text { Depot Operations Manager } \\
\text { - } & \text { Continual Improvement Lead } \\
\text { - } & \text { Head of Communication and Services } \\
\text { - } & \text { Transport Shift Manager } \\
\text { - } & \text { Transformation Manager } \\
\text { - } & \text { Change Manager } \\
\text { - } & \text { Warehouse Dayshift Manager }\end{array}$ \\
\hline EastManage & $\begin{array}{l}\text { Recycling and waste } \\
\text { management services. }\end{array}$ & $\begin{array}{ll}\text { - } & \text { Head of Asset Management } \\
\text { - } & \text { Senior Operations Technician } \\
\text { - } & \text { Maintenance Manager } \\
\text { - } & \text { Plant Manager } \\
\end{array}$ \\
\hline Hinance & $\begin{array}{l}\text { Image-based cheque clearing } \\
\text { services. }\end{array}$ & $\begin{array}{ll}\text { - } & \text { Fraud Team Leader } \\
\text { - } & \text { CUI Supervisor/ Site Lean Agent } \\
\text { - } & \text { Fraud/EPU Supervisor } \\
\text { - } & \text { Site Manager } \\
\end{array}$ \\
\hline FineBank & $\begin{array}{l}\text { Provider of banking } \\
\text { facilities and other financial } \\
\text { and insurance services. }\end{array}$ & $\begin{array}{ll}\text { - } & \text { Design and Transformation Lead } \\
\text { - } & \text { Lean Leader } \\
\text { - } & \text { Design and Delivery Agent } \\
\text { - } & \text { Lean Leader } \\
\text { - } & \text { Lean Change Agent } \\
\text { - } & \text { Programme Support Manager }\end{array}$ \\
\hline MyFinance & $\begin{array}{l}\text { Provider of investment } \\
\text { products and services } \\
\text { including pensions, life } \\
\text { insurance, asset } \\
\text { management, and banking. }\end{array}$ & $\begin{array}{ll}\text { - } & \text { Assistant Team Leader } \\
\text { - } & \text { Operations Manager } \\
\text { - } & \text { Head of Operational Services } \\
\text { - } & \text { Managing Consultant } \\
\end{array}$ \\
\hline
\end{tabular}

Interview transcript data were complemented by research journal notes of social interaction across the case study organizations, provided a dataset revealing variable practitioner perspectives for analysis (Creswell and Poth, 2018). Additionally, multiple sources of secondary data (e.g. charts, reports, lean guides) were collected for contextual analysis. 
Analysis of the dataset was conducted with reference to Netland and Ferdows' (2016) model of lean maturity that holds that through lean maturity higher operational performance is achieved. Via a process of discussion with the senior managers at each organization about their claims to have implemented lean, and observation, the same researcher assessed the lean maturity stage of each of the five organizations, giving consideration to definitions of the four stages of the model (i.e. 1: 'Beginner'; 2: 'InTransition'; 3: ‘Advanced'; 4: 'Cutting Edge') (Table 3).

\section{Findings: Identifying a High-performance HR Bundle for Lean Service Operations}

In this section we report on the HR practices deemed by lean practitioners to be integral to the lean initiatives at the studied organizations. In doing so, we point in the direction of an optimal lean-supportive HR 'bundle' for service organizations.

A common view of lean practitioners was that considered HR practices were vital in the generation of a strong 'lean-oriented' service culture. For example, Amy (Change Manager, HighEnd) commented that 'without engaging our colleagues, we fall short of successfully implementing and sustaining any lean lead change'; while David (Lead Lean Consultant, MyFinance) noted a central concern for 'getting the most out of everyone who comes through the turnstiles every day?', adding that 'you cannot deliver effective lean without a really, really strong core of effective people management'.

Another lean practitioner, Sue (Design and Delivery Agent, FineBank), reiterated this awareness of HR practices being key to the success of lean service projects. When asked how she viewed the role of HR practices in supporting lean she responded emphatically: 
God! Hugely, hugely! What we generally find when we are going to businesses [different departments at FineBank] who haven't had lean ... is that they don't really understand what are the important things that should be included in people management.

This section continues by reporting and discussing six HR practices that emerged from the data (comprising three work practices and three employment practices) as being of significant concern for lean practitioners. These HR practices, that might be conceived of as an emergent 'best practice' HR bundle to support lean service operations, broadly map across to the HR practices identified in our review of the literature (Table 1) with the notable addition of selective recruitment, which does feature in Pfeffer's (1998) formative theorizing on HPWSs. Analytical judgments on the maturity of each of these HR practices were made using the Netland and Ferdows (2016) lean maturity scale (Table 3). How these HR practices related to the success of lean service operations at the five organizations (and thereby why each emerged as an important component of the proposed HR bundle) is now discussed in turn. 
Table 3: Maturity of Lean Service Operations and Key HR Practices across the Case Study Organizations.

(1= Beginner; 2= In-Transition; 3= Advanced; 4= Cutting Edge)

\begin{tabular}{|c|c|c|c|c|c|c|c|c|}
\hline & & & \multirow{2}{*}{\multicolumn{6}{|c|}{ Lean HR Bundle Component Practices }} \\
\hline & & & & & & & & \\
\hline & & & \multicolumn{3}{|c|}{ Work Practices } & \multicolumn{3}{|c|}{ Employment Practices } \\
\hline Organisation & $\begin{array}{l}\text { Lean } \\
\text { Maturity } \\
\text { Stage }\end{array}$ & Comment & $\begin{array}{l}\text { HR } \\
\text { Planning }\end{array}$ & $\begin{array}{l}\text { Team- } \\
\text { working }\end{array}$ & $\begin{array}{l}\text { Employee } \\
\text { Participation }\end{array}$ & $\begin{array}{l}\text { Extensive } \\
\text { Training }\end{array}$ & $\begin{array}{l}\text { Performance } \\
\text { Appraisal, } \\
\text { Recognition and } \\
\text { Reward }\end{array}$ & $\begin{array}{l}\text { Selective } \\
\text { Recruitment }\end{array}$ \\
\hline HighEnd & 1 & $\begin{array}{l}\text { Beginner. } 18 \text { months into a } \\
\text { pilot lean programme. Data } \\
\text { were collected from the } \\
\text { main pilot area. Some } \\
\text { promising initial benefits } \\
\text { reported included recovery } \\
\text { of lost food delivery cages. }\end{array}$ & 1 & 2 & 2 & 2 & 1 & 1 \\
\hline EastManage & 2 & $\begin{array}{l}\text { In-Transition. } \\
\text { Implementation of lean } \\
\text { practices over } 3 \frac{1}{2} \text { year } \\
\text { period had led to } \\
\text { performance improvements } \\
\text { in service delivery. Further } \\
\text { process improvements and } \\
\text { cultural change were set for } \\
\text { implementation. }\end{array}$ & 3 & 2 & 2 & 3 & 2 & 2 \\
\hline Hinance & 2 & $\begin{array}{l}\text { In-Transition. Lean practices } \\
\text { had been implemented over } \\
\text { a } 41 / 2 \text { year period resulting in } \\
\text { multiple benefits including } \\
\text { faster cheque clearing }\end{array}$ & 2 & 3 & 2 & 3 & 3 & 2 \\
\hline
\end{tabular}




\begin{tabular}{|l|l|l|l|l|l|l|l|}
\hline & & $\begin{array}{l}\text { service and cultural change } \\
\text { giving greater focus on } \\
\text { continuous service } \\
\text { improvement. }\end{array}$ & & & & & \\
\hline FineBank & 3 & $\begin{array}{l}\text { Advanced. Eight years of } \\
\text { organizational experience of } \\
\text { lean practices. Operational } \\
\text { performance metrics were } \\
\text { clear and focused, reflecting } \\
\text { mature lean practices and } \\
\text { 'lean culture'. }\end{array}$ \\
\hline MyFinance & 4 & $\begin{array}{l}\text { Cutting Edge. At the time } \\
\text { that data were collected the } \\
\text { company had just celebrated } \\
\text { the ten-year anniversary of } \\
\text { its corporate lean } \\
\text { programme. Organizational } \\
\text { 'lean teams' provided } \\
\text { consultancy on lean } \\
\text { implementation to supply } \\
\text { chain organizations. }\end{array}$ & 4 & 4 & 3 & 4 & 3 \\
\hline
\end{tabular}




\section{Work Practices}

Three work practices concerning how the service operations activities were structured and organized emerged from the data: HR planning, teamworking, and employee participation.

\section{HR Planning}

By concerning itself with HR planning a service organization will ensure that it is and remains resourced with the right number of capable people to deliver the planned-for service. Three elements of HR planning emerged from the thematic analysis as being important for lean service operations: capacity planning, to optimize the size of the workforce and how that workforce is distributed across teams; role profiling, to ensure that the skills of the workforce were pertinent for the lean service resource requirement; and succession planning, to plan for the loss of key personnel.

Three of the case study organizations - Hinance, FineBank, and MyFinance - undertook capacity planning to understand and plan the required human resources to meet customer service demands. This capacity planning activity entailed team-level managers understanding how many people within their teams were capable of performing all the necessary tasks required of the team, and how that related to the operational demands for those capabilities (i.e. if there was a surplus or deficit). As Natalie (Operations Manager, MyFinance) explained, it was essential for her to be able 'to size, plan, organize, structure your team, so that they are not overburdened... [but can meet our] need to clear X amount of work.' 
As well as assisting these organizations in understanding how workload expectations and their capabilities to fulfil workload requirements, capacity planning also assisted them in moving (or 'trading') surplus workers across teams. This enabled a more flexible workforce, capable of doing a variety of work according to operational needs, and improved collaboration.

There's a meeting held [to discuss] ... 'What capacity have you got in your team?' 'Does anybody need any help?' (Tatiana, Fraud Team Leader, Hinance)

Some teams... following the checking of the utilization of [their] staff... move staff across to different teams. (Beth, Lean Change Agent, FineBank)

The data revealed evidence of considered role profiling with lean-specific roles defined to help embed lean principles. This had been particularly important for maturing lean processes at EastManage.

Probably the biggest difference that we've seen since we've started to look at lean... [is that] we look at... how the job role impacts with customers, [and...] across the value chain. (Andy, Head of Asset Management, EastManage)

Role profiling, of service operations and management roles, enabled organizations to rationalize work such that more of it could be done by lower-paid (lower-cost) labour. It also enabled formalization of responsibilities that were embedded with lean rhetoric.

We may separate out complex work and simple work, and that enables us to put the simple work to a clerical member of staff and the complex to a technical member of staff. (Mike, Design and Transformation Lead, FineBank) 
We're talking about expectations of people in roles... What is the role of an assistant team leader? What is the role of a workplace coach? We have provided clarity in their role profiles, around who does what. (David, Lead Lean Consultant, MyFinance)

Across all five organizations specific roles, such as Continual Improvement Lead and Lean Sustainability Consultant, were created with lean-specific responsibilities to direct the organizational lean maturation 'journey' (i.e. to improve performance and/or reduce costs).

We've created a role called CI Champion for where we get a particular member of staff more involved in a particular part of lean. (Tim, CUI Supervisor and Site Lean Agent, Hinance)

Succession planning was seen as being important at HighEnd and Hinance 'to sustain [lean] activity' (Amy, Change Manager, HighEnd). Specifically, it was employed to identify employees with lean expertise who might step into key lean-focussed roles as they became available through staff attrition.

It was quite hard when we did lose a lot of people... so, it's about making sure you've got successors from [among] the colleagues who buy-in to lean. (Mathew, Transport Shift Manager, HighEnd)

\section{Teamworking}

Foundational to a HPWS is an emphasis on semi-autonomous, self-managing, teamworking (Pfeffer, 1998). This chimes with the lean perspective that productivity benefits ensue from there being strong social relationships (McMackin and Flood, 
2019). All five organizations positioned employees within teams to work on specific lean projects, providing an environment for committed, collectively autonomous activity (Klein, 1991), knowledge transfer and peer-supported problem-solving. The most lean-mature teams (at MyFinance and FineBank) were headed up by a team manager who was supported by an assistant team manager and a workplace coach. The assistant team managers had responsibilities for removing operational bottlenecks and ensuring that service processes had a smooth 'flow' (Womack and Jones, 1996). The workplace coaches typically had responsibilities for managing and improving work quality (Anand et al., 2009). Additionally, specialized teams had been established at four of the organizations to oversee and support corporate lean programmes. Specialized 'Lean Improvement Action Teams’ at East Manage and HighEnd supported functional service teams by providing lean consultancy and training services, thus assisting managers in embedding lean within their teams.

We've got teams in the business solely dedicated to... Lean... and continuous improvement. (Dayle, Senior Operations Technician, EastManage)

Such teams were highly regarded by the lean practitioners for: (i) bringing 'an all-round view of a problem' (Andy, Head of Asset Management, EastManage) via objective feasibility analysis of continuous improvement ideas, and (ii) their rhetorical capabilities to diffuse lean principles across the workforce (Green, 2004).

So much change has happened. I don't think a lot of it would have ever happened if it was not for our lean team because they've driven operations to actually change their mind-set to a culture of: 'our customers do come first'. (Natalie, Operations Manager, MyFinance) 


\section{Employee Participation}

Lean practitioners reported encouraging the voluntary participation of employees in the organizational lean journey. Participation, in this sense, is a strategic decision to purposively ease managerial control, allowing employees to exert influence over their work and working conditions, improvize and innovate (Strauss, 2006). The observed reality was that there existed a tension between empowering employees to innovate service quality improvements (Altinay et al., 2008) yet insisting upon consistent standardized service provision in line with the scientific management principles that are fundamental to lean services (Sundbo, 2002). It was widely recognized at the more leanmature organizations that management had to consciously rein in any instinct to overexert control (Raja Sreedharan et al., 2018). As one lean practitioner commented:

If you just try to force the change, it is likely to unravel. (Natalie, Operations Manager, MyFinance.)

It was recognized by several of the lean practitioners that their role was to engender in workers an emotional-level response of 'buying-in' to lean principles.

I think the biggest issue is getting everyone involved, getting an understanding for everybody. (Andy, Head of Asset Management, EastManage.)

It was found that many lean practitioners had developed an awareness of the importance of addressing employee resistance to lean initiatives:

We've probably spent $80 \%$ of the time with the minority of the people that don't buy-in to it... the sort of detractors, who say, you know, 'well we've always done it like this. It's always worked okay. Why do we need to change?' (Philip, Plant Manager, EastManage.) 
Central to employee participation strategies were effective communication practices, including information sharing (Pfeffer, 1998), with employees. The nature of this communication was found to be contingent upon contextual features. Three of the five case study organizations (MyFinance, EastManage, and HighEnd) operated with recognized trade unions. As such, to avoid organized employee resistance, lean managers spoke of negotiating with the unions over lean-informed changes to working practices. The data from these three studies point to the importance of involving any recognized trade union in lean adoption. The lean practitioners at these organizations expressed benefits from having 'honest conversations' about management expectations from lean projects in particular work areas. An effective management tactic in such negotiations, as employed at EastManage and HighEnd, was an offer to trial 'lean' processes before they were formally adopted with the option of reverting to previous service operating processes remaining available.

We have always involved them from day one ... We have had the meetings. The union guys would give their thoughts... Nothing was a surprise, nothing was a secret... It was like, well, let's try it; if it doesn't work, we revert back to the old way of doing it. (Mathew, Transport Shift Manager, HighEnd)

The data also point to the importance in such negotiations of 'selling' the benefits of 'lean' from the perspective of the workforce; for example, the opportunity for employees to learn new marketable skills, and more secure employment.

At the least lean-mature organizations, EastManage and HighEnd, the assertive change management technique of 'creating a sense of urgency' (Kotter, 2012) was tactically employed as a central element of the organizational rhetoric communicated to employees to achieve their 'buy in' to the lean programme. The key message repeated 
to generate employee support was that lean was the only way forward if the company was to remain competitive and ongoing employment protected.

You need to change your mind-set [from...] 'what's good for the business?' to 'how does that benefit a colleague?' So, whether that be long term success of the business, or profitability of the business... we all get job security... That's the way you need to get people. (Robert, Depot Operations Manager, HighEnd)

Consistent with other research that notes the importance of listening to 'the employee voice' and addressing concerns in order to 'soften' the rationalizing forces of managerial control implicit within lean thinking (Strauss, 2006), management across all organizations gave employees multifarious opportunities (including via training initiatives and open communication forums) to communicate their views. There was though an undercurrent of tension between listening to employee voices and yet insisting on the primacy of management to implement change.

We had to help with some lean awareness sessions and air everybody's views, get anything out on the table, to then go ahead with it [lean]. (Tatiana, Fraud Team Leader, Hinance)

Other channels, enabling employee input to how lean was implemented included: the 'moan zone' (EastManage), 'graphite board' (HighEnd), and 'bug board' (Hinance) to capture employees' concerns about lean in their workplace, and the 'idea box' (EastManage; HighEnd), and 'my CI' (MyFinance; Hinance) to capture employees' ideas on how to improve service provision. Some of the interviewed lean practitioners noted how these mechanisms not only facilitated more efficient ways of 
working but also served to value individual employees. As Frank (Lean Leader, FineBank) put it: 'There is a very heavy focus on people and respect for ideas.'

Management across organizations also had a more general concern for facilitating effective, communicative and collaborative relationships between employees working on lean projects and providing lean services.

It is just common sense... get people involved to say, 'Hang on a minute, if I change this, this might make my job easier, it will make your job easier, but Fred's job over there, it makes that ten times worse. (Ian, Distribution General Manager, HighEnd)

The data also reveal the prevalent use of lean-oriented meetings at which worker involvement was expected. Such meetings were often given descriptive names, for example, performance meetings (FineBank; Hinance), visual meetings (Hinance; EastManage), champion meetings (MyFinance), huddle meetings (FineBank; HighEnd), and bug meetings (Hinance).

An example of how innovation and communication operated symbiotically to good effect was provided by Andy (Head of Asset Management, EastManage):

[We have] just set up a project tracker to... promote collaboration and make sure that we're not repeating work. So, as soon as a project is going in China, and somebody has got a similar project in Germany, and someone in the UK, we will pull them together to form a project group.

\section{Employment Practices}


Three employment practices concerning how management interact with employees emerged from the data as being particularly pertinent for effective lean service operations: selective recruitment; performance appraisal, recognition and reward; and extensive training.

\section{Selective Recruitment}

The HR selection processes of the organizations all placed, to different degrees, an emphasis on candidates' suitability for working under lean management methodologies. Specifically, selective recruitment (Pfeffer, 1998) was often employed to bring in leanaware workers. Job advertisements and descriptions were worded to attract candidates with prior exposure to lean, and those charged with selecting candidates were typically lean-oriented managers. As David (Lead Lean Consultant, MyFinance) explained: 'Individuals, who have gone through a lean intervention... are thinking differently about the people that they recruit'. However, shortlisting of candidates typically privileged those with pertinent technical knowledge.

I don't think we'd go out and look for a shift manager purely based on [having a] continuous improvement, lean background rather than their industrial background. (Michael, Site Manager, Hinance)

However, candidates with experience of working in lean environments were typically prioritized. As Jenny (Head of Operational Services, MyFinance) noted, 'If someone came along... and they know lean, they will be straight in... [considered as] a strong individual'.

Recruitment interviewing typically sought to elicit candidates' levels of lean knowledge and their attitudes towards change and lean service provision. Selection decisions were 
typically based on prior exposure to lean practices and assessments of: (i) technical knowledge, (ii) attitude to change, and (iii) disposition towards lean. Typically, and especially in the more 'lean-mature' organizations, the weighting attributed to each of these considerations depended upon the role being recruited for. For service support roles that were defined in terms of lean expertise required, the selection activities sought to firstly identify those candidates whose technical knowledge related best to the role and secondly those who had lean-related experience. Lean know-how was not necessarily seen as being essential: where the best candidates from assessment of technical skills lacked specific lean know-how, they were still recruited but then enrolled in lean-related training.

There are things [we look for] like, if they've got an awareness of Lean Six Sigma, continuous improvement or any other sort of quality management systems.... [but] if they've got the technical background and the operational background... [that] would far outweigh the requirements to have lean understanding... because we believe they'll get embedded into the culture. (Andy, Head of Asset Management, EastManage)

The findings confirm the importance of having a recruitment strategy that is geared towards supporting lean service operations (Suárez-Barraza and Ramis-Pujol, 2010). They also suggest that as more organizations adopt lean and as those organizations travel further along the lean maturity path (and have more lean-specific roles) so organizations increasingly expect to recruit people with experience of working with lean. As Amy (Change Manager, HighEnd) said: 'If the role is specifically for lean improvement ... [recruitment] is very much focused on this skillset'. 


\section{Performance Appraisal, Recognition, and Reward}

The data from across all five organizations, but particularly the more lean-mature ones, point to there being organizational benefits from investing in formal performance appraisal processes. Firstly, to complement expectation of continuous service improvement (George, 2003), formal appraisal was used to facilitate ongoing individual performance improvement (or work intensification) via the routine setting of individual lean-oriented performance targets:

They know exactly what's going to be discussed in the meetings: Lean... If you are constantly meeting an objective... then we move the bar higher. (Tim, CUI Supervisor and Site Lean Agent, Hinance)

Secondly, they provided a Taylorist mechanism for identifying gaps between individual performance levels and expected performance targets (Taylor, 1911).

There is no room for someone to say... 'I process ten applications a day', the person sitting next to him to say, 'well, I do forty'... We've put models in place to...say, 'Well actually, on average, you should be doing 25-30'. (Jenny, Head of Operational Services, MyFinance)

The data reveal that where such gaps were identified, training and development initiatives, including individual coaching, were typically employed to good effect.

We let them know their performance, and if they are struggling with anything... [we] work with them to build them up. (Tatiana, Fraud Team Leader, Hinance) 
While performance targets were routinely set across all five organizations in line with lean principles there was no evidence found of management taking disciplinary action against individuals for failing to meet targets. Rather, an emphasis was placed on coaching and supporting employees to improve their individual performance levels.

In line with the relationship between awarding non-financial rewards and employee commitment to lean principles (Netland et al., 2015), all five organizations used reward and recognition tactics beyond the contractual reward of payment for labour. The most lean-mature of the organizations operated a bonus scheme whereby employees were rewarded for hitting customer-oriented key performance indicator targets. Other reward and recognition mechanisms were employed to send a cultural message that continuous service improvement innovations and other pro-lean behaviours were valued. These included: highlighting individuals' efforts on office noticeboards, sending employees 'thank you' letters, issuing certificates, awarding extra days of annual leave, and monetary bonuses:

This year, the first idea [adopted], we paid $£ 350 \ldots$ But it's not just about throwing lots of money at it, it's doing it in the right way... pictures on the board, shaking hands. (Ian, Distribution General Manager, HighEnd)

We have... a 'Make a Difference' scheme where we can highlight where people have gone above and beyond to generate good ideas for the customers and the business. (Frank, Lean Leader, FineBank)

We have got a 'Bright Ideas' suggestion scheme... The best idea each month gets a prize ... (Robert, Depot Operations Manager, HighEnd) 
The objectives of such rewards were thus to nurture a high-performance pro-lean culture and give management a greater assurance on the retention of the key talent who embodied that culture through their actions and ideas (Sangwa and Sangwan, 2017).

We believe that by putting a monetary reward on it, it may influence people [to buy-in to lean]. (Andy, Head of Asset Management, EastManage)

The literature on workplace motivation highlights how crude monetary reward mechanisms may not always be the most appropriate to employ because employees are motivated by different rewards, contingent on the context (Altinay et al., 2008; Pink, 2009). The context of lean adoption is shown to be a significant contingent factor with both Hinance and HighEnd reassessing their reward and recognition practices:

Lean has helped us recognize that we didn't do enough of [rewarding employees] ... Unless the current staff are comfortable about making improvements... they're not going to come forward because they feel that they're putting themselves out of the job potentially. (Michael, Site Manager, Hinance)

One tactic employed at HighEnd to recognize (rather than reward) employees' support for a lean culture was to release them from their routine responsibilities to work on service improvement initiatives:

You could have the brilliantest idea in the world but if you are not going to be released off your job... you're never going to implement it. (Bill, Head of Communication and Services, HighEnd)

More strikingly though, the data also point to management good intentions having the potential for damaging rather than boosting commitment to lean. For example, lean 
practitioners at HighEnd reported on how inappropriate or inadequate rewards, such as a mobile phone top-up voucher, a box of chocolates, or a bottle of wine, had been regarded as being derisory:

Before it was always a bottle of wine, something very nominal, you know, £10, $£ 20$ tops... We've now realized that... you come up with an idea and it saves $£ 5000, £ 10000$, whatever; then to give you a bottle of wine, you will be like,

'Okay, thank you for that', you know, in a sarcastic way. (Ian, Distribution General Manager, HighEnd)

This example serves as a reminder that management must be practised artfully, with regard for emotional intelligence as well as rationality. It has been suggested that 'hard' HR appraisal mechanisms that solely focus on quantitative metrics have acted as barriers to successful lean implementations (Raja Sreedharan et al., 2018), and the data here suggest that a 'softer' HR appraisal mechanism offers greater potential for achieving the objective of the workforce being committed to lean methods of working.

\section{Extensive Training}

Just as well-considered performance appraisal and reward processes might contribute to successful lean service operations, so the literature also highlights the importance of a training strategy to ensure that employees are adequately skilled to implement lean (Bonavia and Marin-Garcia, 2011; Raja Sreedharan et al., 2018). In line with this, all five organizations had invested in lean-specific training initiatives. East Manage trained employees in 'continuous improvement' techniques. A specific training objective at MyFinance was to achieve employee commitment, i.e. 'to get people on the lean journey' (Dan, Assistant Team Leader, MyFinance). To achieve this management 
training emphasized the lean principle of 'respect for people' (Ohno, 1988). Bill (Head of Communication and Services, HighEnd) spoke of lean 'cultural change' being supported by 'more training now than there ever was... they're coming thicker and faster at the moment'. This included cross-training and up-skilling to enable greater management flexibility to redeploy staff across the organization. In line with this, Tim (CUI Supervisor and Site Lean Agent, Hinance) reported on there being 'an expectation that everybody builds upon lean-related knowledge and skills.'

The data collected from the more lean-mature organizations also revealed how such lean-related training programmes facilitated employees shifting to an alternative career path, taking on roles as lean consultants/practitioners/experts and serving on specialized 'improvement action teams' that provided lean consultancy services.

We are giving them opportunities... to learn new skills... new techniques and tools they can apply... skills they can take away. (Tim, CUI Supervisor and Site Lean Agent, Hinance)

While this research confirms that extensive training is important for lean service operations, it is shown to be insufficient unless provided in a broader context of other lean-oriented work and employment practices. In the next section the importance of this holistic perspective is discussed.

\section{Discussion}

The findings of this study point to there being common elements that might be conceptualized as a high-performance 'best practice' HR bundle for lean service operations, working symbiotically alongside other lean 'bundles' (e.g. TQM and JIT) 
(Shah and Ward, 2003; Dal Pont et al., 2008). What emerges is a picture of an integrated lean maturation - or organizational learning (Senge, 1992) - process in which lean managers proactively take steps to analyse and improve HR practices at strategic and operational levels symbiotically with broader lean activities. However, this study also illustrates how this often occurs implicitly rather than in a systematic way that might offer opportunities for greater management control over HR practices and thus better enable their continuous improvement.

This study has identified three work practices and three employment practices that might each be identified as a key component of a high-performance 'best practice' HR bundle for optimising lean service operations. The multiple case study approach taken has revealed how, just as lean service operations processes might be continuously improved (i.e. mature towards greater efficiency), so related HR processes might also contemporaneously improve.

By re-conceptualising the six identified HR practices as processes we might usefully define the scope of each process, roles with assigned accountabilities and responsibilities, and appropriate metrics (including key performance indicators) and other qualitative data to be captured. The qualitative interview data presented here has suggested that listening to the ideas and concerns of operational level service employees is important for the lean HR maturation process since it generates important information for improving HR processes (e.g. for enhancing participation and reward initiatives). Thus the study points to how the lean principle of continuous improvement (kaizen) i.e. that 'everyone participates in the process; and improvements result from the... experience of workers' (Evans, 2011, p. 141) - might be usefully applied to each of the six HR processes. By encouraging employees to constructively voice their experiences 
of being subjected to each process, organizations might expect to achieve greater HR process efficiency, and benefit from a more engaged and committed workforce and increased organizational performance (Morrison, 2011; Burke, 2013).

The umbrella concept of the HR bundle is important for facilitating holistic management control of the HR practices. Thus, an 'HR bundle' process might additionally be implemented to offer higher-level oversight of HR for lean service managers. This process might define and capture its own HR metrics to monitor the effectiveness of interactions across the lower-level processes. Two examples of such interactions are as follows: (i) information sharing is a feature of 'employee participation' but also pertains to 'team working'; (ii) the processes of 'extensive training' and 'performance appraisal, recognition and reward' would share an interest in measurements relating to the impact of training on performance levels.

Greater control of the HR bundle maturation process would facilitate a systemic commitment to continuous improvement as advocated in the lean practitioner literature (George, 2003). In this regard, the PDCA (plan, do, check, act) cycle of improvement (Deming, 1994; Bateman and David, 2002) might be usefully applied to the emergent 'high performance' lean HR bundle (Figure 1 and Table 4). 
Figure 1: PDCA cycle of improvement as applied to the emergent 'high performance' HR bundle for lean service operations.

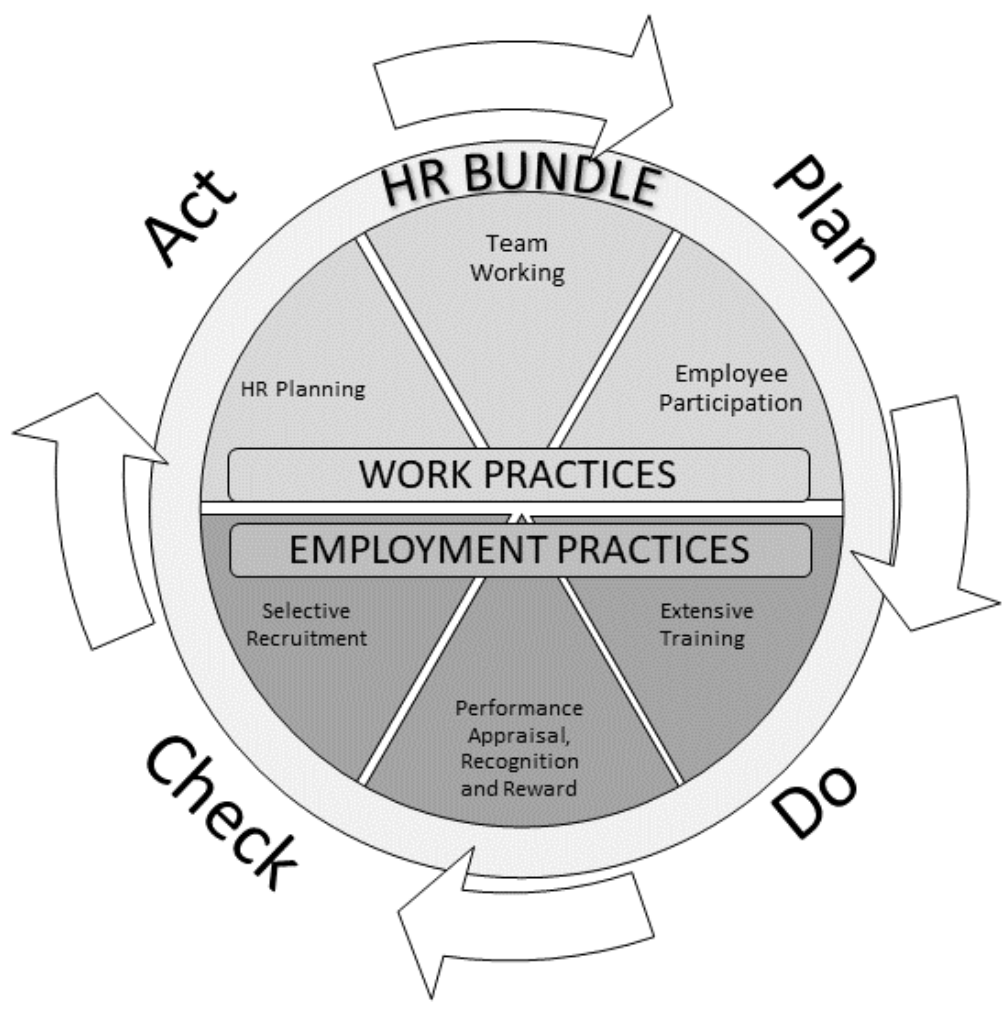

This study points to an implicit maturation process relating to these HR processes. It is proposed that by applying the PDCA cycle of improvement, the HR maturation process might be placed under greater, and lean-appropriate, managerial control. While applying PDCA to the HR bundle is consistent with lean thinking (Bateman and David, 2002), further field research is required to demonstrate its effectiveness in practice. 
Table 4: Application of PDCA Improvement Cycle to the Lean 'HR Bundle' Process and Underlying 'HR Practice’ Processes.

\begin{tabular}{|c|c|c|}
\hline & $\begin{array}{l}\text { High performance HR Bundle } \\
\text { Process }\end{array}$ & $\begin{array}{l}\text { Underlying HR (Work and } \\
\text { Employment) Practice Processes }\end{array}$ \\
\hline Plan & $\begin{array}{l}\text { Define the bundle: What underlying } \\
\text { HR processes require process } \\
\text { management? How do they } \\
\text { interact? } \\
\text { - Define process roles, including } \\
\text { process owner; accountabilities and } \\
\text { responsibilities. } \\
\text { Establish metrics and } \\
\text { supplementary qualitative data } \\
\text { relating to the intersections between } \\
\text { low-level processes. }\end{array}$ & 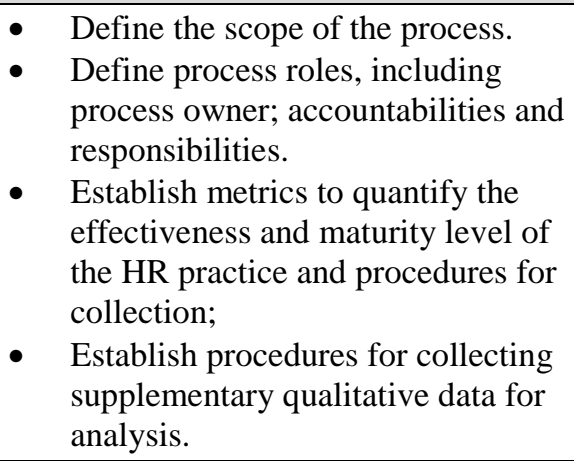 \\
\hline Do & $\begin{array}{ll} & \text { Implement plan. } \\
\text { - } & \text { Collect quantitative and qualitative } \\
\text { data. }\end{array}$ & $\begin{array}{l}\text { - Implement planned activities } \\
\text { relating to the process } \\
\text { - Collect quantitative and qualitative } \\
\text { data }\end{array}$ \\
\hline Check & $\begin{array}{l}\text { Draw together and analyse data } \\
\text { provided by the process owners of } \\
\text { the underlying processes and the } \\
\text { intersectional data to better } \\
\text { understand strengths and areas for } \\
\text { improvement. }\end{array}$ & $\begin{array}{l}\text { - Analyse quantitative and qualitative } \\
\text { data to better understand strengths } \\
\text { and areas for improvement. }\end{array}$ \\
\hline Act & $\begin{array}{l}\text { - Coordinate improvement initiatives } \\
\text { from the (six) underlying HR } \\
\text { practice processes. }\end{array}$ & $\begin{array}{l}\text { - Take actions to address areas for } \\
\text { improvement. }\end{array}$ \\
\hline
\end{tabular}

\section{Conclusion}

While acknowledging that the very notion of 'best practice' HR is problematic

(Marchington and Grugalis, 2000) the multiple case study approach taken here has enabled a rigorous consideration of how HR practices in the field of service operations are being applied by companies that claim to have gained competitively through concerted efforts to apply lean principles to their activities. From this assumption as to the extent to which 'best practice' generalizations might be drawn, this study supports the notion that attention to the design and management of an HR bundle is important for successful adoption and maturation of a lean approach to service operations. Previous 
research into lean (manufacturing) settings has shown a lack of consensus on what HR practices should significantly feature in the lean HR bundle, although five particular practices recur across this research: HR planning, teamworking, employee participation, training, and reward. This research contributes to the literature by drawing on qualitative data collected from lean practitioners to, in the main, confirm these as key elements of a 'high performance' HR bundle for lean service operations. It points the way forward to addressing risks associated with failure of lean process improvement initiatives: employee resistance, lack of commitment, and skills/know-how (Antony et $a l ., 2019)$. It also suggests how the HR practices identified here as being the most important might be usefully presented as individual HR processes, enabling greater managerial control. However, this study also illustrates how 'reward' is not a sufficiently independent HR practice to warrant being managed as a process. Rather it is re-presented as a feature of an integrated HR practice process of 'performance appraisal, recognition and reward'. Additionally, via the thematic analysis research approach taken and in line with the HPWS literature (Pfeffer, 1998), it became clear that 'selective recruitment' should be included as a key constituent of a 'high-performance' HR bundle for lean services.

Whereas previous research has sought to show statistically-significant multi-level relationships between lean and particular HR practices (Shah and Ward, 2003; Ramadas and Satish, 2018) the qualitative approach taken here offers analysis of the 'real world' perspectives of lean practitioners. It thus contributes to the literature by providing a deeper understanding of how HR practices are integral to lean service operations across a range of service organizations at different stages of lean maturity. In doing so it makes a practical contribution by presenting to immature lean service organizations a 'high- 
performance' HR bundle, comprising a set of six 'HR practice' processes, for implementation.

Service organizations embarking upon their own journey towards lean maturity and those further along the road might engage with the findings of this study to give greater consideration, within their own unique contexts, to the integration of their service operations with their HR practices. Specifically, a key practical contribution of this study is that certain HR practices associated with HPWS theory should be embraced as being integral, rather than separate from, lean service operations. As such, lean service managers should proactively involve themselves in the management of these HR practices even if their organizations' HR functions retain accountabilities and responsibilities for those practices (i.e. where the HR practices lay outside of the organizational remit of lean service managers). In such a structural context, they might need to work closely with the HR function to recast those HR practices found here to be integral to lean service provision as 'lean HR processes' within a 'best practice' HPWS. Once established as processes integral to lean service operations they might then be managed with a sharper focus on business outcomes associated with the services provided by the organization. For example, they might be geared towards achieving incremental continuous improvement to service effectiveness and efficiency.

Via its qualitative approach, the research has provided important knowledge on how HR practices are implemented in lean service contexts. For example, lean practitioners have reported on how they ensure that the most suitable people are appointed to defined roles and positioned within a carefully-considered teamworking organizational structure, and then afforded appropriate autonomy. The reported data suggest that, in combination, the 
six HR practices identified for inclusion in the lean service HR bundle facilitate the workforce in embracing lean thinking and work process changes.

The qualitative approach taken, listening to the voice of experienced lean practitioners, has resulted in the formation of an empirically-informed 'best practice' HR process for lean service operations that acknowledges the importance of effective communication, adopts a contingent approach to employee relations, and recognizes the dangers of inappropriate reward practices. As such, the study contributes to the lean operations literature by elaborating, refining and extending the role that HR practices, performed at strategic, tactical and operational management levels, play in lean service operations.

As a theoretical contribution the lean HR bundle has been conceived as a set of six interconnected 'HR practice' processes, overseen by an independent 'HR bundle' process (Figure 1). Conceived thus, lean continuous improvement techniques (e.g. PDCA) might be applied to each of these processes so that they mature over time. This maturation process was implicit in the activities and experiences of the lean practitioners interviewed for this study. That is, lean thinking was implicitly applied to people management practices as lean managers learned what was effective and refined what they did accordingly. Further research might entail continuous improvement monitoring over time following a lean service providing organization's adoption of the proposed 'HR bundle' process and its constituent 'HR practice' processes. Such research might usefully be designed to incorporate the collection of both operationallevel 'employee voice' and 'managerial voice' data for purposes of comparison. 


\section{References}

Altinay, L., Altinay, E. and Gannon, J. (2008), "Exploring the relationship between the human resource management practices and growth in small service firms", The Service Industries Journal, 28(7): 919-937.

Anand, G., Ward, P.T., Tatikonda, M.V. and Schilling, D.A. (2009), "Dynamic capabilities through continuous improvement infrastructure", Journal of Operations Management, 27(6): 444-461.

Antony, J., Lizarelli, F.L., Fernandes, M.M., Dempsey, M., Brennan, A. and McFarlane, J. (2019), "A study into the reasons for process improvement project failures: results from a pilot survey", International Journal of Quality and Reliability Management, 36(10): 1699-1720.

Appelbaum, E., Bailey, T., Berg, P. and Kalleberg, A. (2000), Manufacturing Advantage: Why High-Performance Work Systems Pay Off. ILR Press, Ithaca, NY.

Baker, S.E. and Edwards, R. (2012), How many qualitative interviews is enough?, NCRM. Available at: http://eprints.ncrm.ac.uk/2273/

Bateman, N. and David, A. (2002), "Process improvement programmes: a model for assessing sustainability", International Journal of Operations \& Production Management, 22(5): 515-526.

Bazeley, P. and Jackson, K. (2013), Qualitative Data Analysis with NVivo, SAGE Publications, London.

Braun, V. and Clarke, V. (2013), Successful Qualitative Research: A Practical Guide for Beginners, SAGE Publications, London.

Browning, V., Edgar, F., Gray, B. and Garrett, T. (2009), "Realising competitive advantage through HRM in New Zealand service industries", The Service Industries Journal, 29(6): 741-760.

Bryman, A. (2001), Social Research Methods. Oxford University Press, Oxford.

Bello-Pintado, A. (2015), "Bundles of HRM practices and performance: Empirical evidence from a Latin American context", Human Resource Management Journal, 25(3): 311-330.

Bonavia, T. and Marin-Garcia, J.A. (2011), "Integrating human resource management into lean production and their impact on organisational performance", International Journal of Manpower, 32(8): 923-938.

Bowen, D.E. and Youngdahl, W.E. (1998), "Lean" service: in defense of a productionline approach', International Journal of Service Industry Management, 9(3): 207-225. 
Boxall, P. and Macky, K. (2009), "Research and theory on high-performance work systems: progressing the high involvement stream", Human Resource Management Journal, 19(1): 3-23.

Burke, R.J. (2013), "Encouraging Voice: why it matters", in Burke, R.J. and Cooper, C.L. (Eds.), Voice and Whistleblowing in Organizations: Overcoming Fear, Fostering Courage and Unleashing Candour, Edward Elgar, Cheltenham, United Kingdom, pp. $3-71$.

Creswell, J.W. and Poth, C.N. (2018), Qualitative Inquiry and Research Design: Choosing Among Five Approaches, SAGE Publications, United States.

Dal Pont, G., Furlan, A. and Vinelli, A. (2008), 'Interrelationships among lean bundles and their effects on operational performance', Operations Management Research, 1(2): $150-158$.

de Koeijer, R.J., Paauwe, J. and Huijsman, R. (2014), “Toward a conceptual framework for exploring multilevel relationships between Lean Management and Six Sigma, enabling HRM, strategic climate and outcomes in healthcare", The International Journal of Human Resource Management, 25(21): 2911-2925.

De Saá Pérez, P. and García Falcón, J.M. (2004), “The influence of human resource management in savings bank performance", The Service Industries Journal, 24(2): 5166.

Delery, J. and Gupta, N. (2016), "Human resource management practices and organizational effectiveness: internal fit matters", Journal of Organizational Effectiveness: People and Performance, 3(2): 139-163.

Delgado, C., Ferreira, M. and Branco, M.C. (2010), "The implementation of lean Six Sigma in financial services organisations", Journal of Manufacturing Technology Management, 21(4): 512-523.

Deming, W.E. (1994), Out of the Crisis, $2^{\text {nd }}$ ed., MIT, Cambridge, MA.

Evans, J.R. (2011), Quality Management, Organization, and Strategy, $6^{\text {th }}$ International ed., South-Western Cengage Learning, Mason, $\mathrm{OH}$.

George, M.L. (2003), Lean Six Sigma for Service: How to Use Lean Speed and Six Sigma Quality to Improve Services and Transactions, McGraw-Hill, New York, NY.

Gittell, J.H., Seidner, R. and Wimbush, J. (2010), “A Relational Model of How HighPerformance Work Systems Work”, Organisation Science, 21(2): 490-506.

Glaser, B.G., and Strauss, A. L. (1967), The Discovery of Grounded Theory: Strategies for Qualitative Research. Chicago: Aldine.

Gomm, R., Hammersley, M. and Foster, P. (2000), Case Study Method: Key Issues, Key Texts. SAGE Publications, London. 
Gratton, L. (2000), Living Strategy: putting people at the heart of corporate purpose. Pearson, Harlow.

Gray, D.E. (2016), Doing Research in the Business World, SAGE, London.

Green, S.E. (2004), "A rhetorical theory of diffusion", Academy of Management Review, 29(4): 653-669.

Guest, D.E. (2017), "Human resource management and employee well-being: towards a new analytic framework", Human Resource Management Journal, 27(1): 22-38.

Harley, B. (2015), "The one best way? 'Scientific' research on HRM and the threat to critical scholarship”, Human Resource Management Journal, 25(4): 399-407.

Holbeche, L. (1998), Motivating People in Lean Organisations, ButterworthHeinemann, Oxford.

Holbeche, L. (1999), Aligning Human Resources and Business Strategy, Elsevier Butterworth-Heinemann, Oxford.

Holweg, M. (2007), “The genealogy of lean production”, Journal of Operations Management, 25(2): 420-437.

Huselid, M.A. (1995), "The impact of human resource management practices and turnover, productivity, and corporate financial performance", Academy of Management Journal, 38(3): 635-672.

Klein, J.A. (1991), "A Reexamination of Autonomy in Light of New Manufacturing Practices", Human Relations, 44(1): 21-38.

Kotter, J.P. (2012), Leading Change, HBR Press, Boston, MA.

Krafcik, J.F. (1988), "Triumph of the lean production system", MIT Sloan Management Review, 30(1): 41-52.

Lindskog, P., Hemphälä, J. and Eriksson, A. (2017), "Lean tools promoting individual innovation in healthcare", Creativity and Innovation Management, 26(2): 175-188.

Liker, J.K. and Meier, D.P. (2007), Toyota Talent: Developing your People the Toyota Way, McGraw-Hill, New York, NY.

Lorden, A.L., Zhang, Y., Jin, Z. and Cote, M.J. (2014), "Measures of success: the role of human factors in lean implementation in healthcare", Quality Management Journal, 21(3): 26-37.

MacDuffie, J.P. (1995), "Human Resource Bundles and Manufacturing Performance: Organisational Logic and Flexible Production Systems in the World Auto Industry", Industrial and Labor Relations Review, 48(2): 197. 
Malladi, S., Dominic, P.D.D. and Kamil, A. (2011), "Lean principles in IT services: a case study on implementation and best practices", International Journal of Business Information Systems, 8(3): 247-268.

Marchington, M. and Grugalis, I. (2000), “'Best practice' human resource management: perfect opportunity or dangerous illusion?", International Journal of Human Resource Management, 11(6): 1104-1124.

Martínez-Jurado, P.J., Moyano-Fuentes, J. and Gómez, P.J. (2013), "HR management during lean production adoption”, Management Decision, 51(4): 742-760.

McMackin, J. and Flood, P. (2019), "A theoretical framework for the social pillar of lean”, Journal of Organizational Effectiveness: People and Performance, 6(1): 39-55.

Moody, K. (1997), Workers in a Lean World: Unions in the International Economy, Verso, London.

Morrison, E.W. (2011), "Voice and Silence within Organizations: literature review and directions for future research", Academy of Management Annuals, 5: 373-412.

Mostafa, S., Lee, S., Dumrak, J., Chileshe, N. and Soltan, H. (2015), "Lean thinking for a maintenance process", Production \& Manufacturing Research, 3(1): 236-272.

Netland, T.H. and Ferdows, K. (2016), "The S-Curve Effect of Lean Implementation", Production and Operations Management, 25(6): 1106-1120.

Netland, T.H., Schloetzer, J.D. and Ferdows, K. (2015), "Implementing corporate lean programs: The effect of management control practices", Journal of Operations Management, 36: 90-102.

Ohno, T. (1988), Toyota Production System: Beyond Large-scale Production, CRC Press, New York, NY.

Panizzolo, R. (1998), “Applying the lessons learned from 27 lean manufacturers.: The relevance of relationships management", International Journal of Production Economics, 55(3): 223-240.

Pfeffer, J. (1998), The Human Equation, Harvard Business School Press, Boston, MA.

Pink, D.H. (2009), Drive: The Surprising Truth About What Motivates Us, Riverhead Books, New York, NY.

Power, D. and Sohal, A.S. (2000), "Human resource management strategies and practices in Just-In-Time environments: Australian case study evidence", Technovation, 20(7): 373-387.

Radnor, Z. and Johnston, R. (2013), "Lean in UK government: internal efficiency or customer service?”, Production Planning \& Control, 24(10-11): 903-915.

Raja Sreedharan, V., Balagopalan, A., Murale, V., and Arunprasad, P. (2018), "Synergising Lean Six Sigma with human resource practices: evidence from literature 
arena", Total Quality Management \& Business Excellence, DOI: 10.1080/14783363.2018.1439374

Ramadas, T. and Satish, K.P. (2018), "Identification and modeling of employee barriers while implementing lean manufacturing in small- and medium-scale enterprises", International Journal of Productivity and Performance Management, 67(3): 467-486.

Sangwa, N.R. and Sangwan, K.S. (2017), "Development of an integrated performance measurement framework for lean organisations", Journal of Manufacturing Technology Management, 29(1): 41-84.

Senge, P.M. (1992), The Fifth Discipline: The Art \& Practice of the Learning Organization. Random House, London.

Shah, R. and Ward, P.T. (2003), "Lean manufacturing: context, practice bundles, and performance", Journal of Operations Management, 21(2): 129-149.

Shah, R., Chandrasekaran, A. and Linderman, K. (2008), "In pursuit of implementation patterns: the context of Lean and Six Sigma", International Journal of Production Research, 46(23): 6679-6699.

Sony, M., Naik, S. and Therisa, K.K. (2018), "Why do organizations discontinue Lean Six Sigma initiatives?", International Journal of Quality and Reliability Management, 36(3): 420-436.

Sparrow, P., Hird, M. and Cooper, C. (2014), "Lean management and organisational effectiveness", in Sparrow, P., Hird, M. and Cooper, C. (Ed.), Do we need HR? Repositioning people management for success, Palgrave Macmillan, United Kingdom, pp. 86-110.

Sparrow, P. and Otaye-Ebede, L. (2014), "Lean management and HR function capability: the role of HR architecture and the location of intellectual capital", The International Journal of Human Resource Management, 25(21): 2892-2910.

Staats, B.R., Brunner, D.J. and Upton, D.M. (2011), "Lean principles, learning, and knowledge work: Evidence from a software services provider", Journal of Operations Management, 29(5): 376-390.

Strauss, G. (2006), "Worker participation: some under-considered issues”, Industrial Relations, 45(4): 778-803.

Suárez-Barraza, M.F. and Ramis-Pujol, J. (2010), "Implementation of Lean-Kaizen in the human resource service process: A case study in a Mexican public service organisation", Journal of Manufacturing Technology Management, 21(3): 388-410.

Sundbo, J. (2002), “The service economy: Standardisation or customisation?" The Service Industries Journal, 22(4): 93-116.

Taylor, F.W. (1911), Principles of Scientific Management, Harper, New York. 
Vashishth, A., Chakraborty, A. and Antony, J. (2017), "Lean Six Sigma in financial services industry: a systematic review and agenda for future research", Total Quality Management \& Business Excellence, pp. 1-19

Vidal, M. and Hauptmeier, M. (2014), "Comparative Political Economy and Labour Process Theory: Towards a Synthesis”, in Hauptmeier, M. and Vidal, M. (Eds.), Comparative Political Economy of Work, Palgrave MacMillan, Basingstoke, pp. 1-32.

Voss, C., Johnson, M. and Godsell, J. (2016), "Case research”, in Karlsson, C. (Ed.), Research Methods for Operations Management, Routledge, London and New York, NY, pp. 165-165.

Weiss, D.S. (2000), High Performance HR: Leveraging Human Resources for Competitive Advantage, John Wiley \& Sons, Ontario.

Womack, J.P. and Jones, D.T. (1996), "Beyond Toyota: How to Root Out Waste and Pursue Perfection”, Harvard Business Review, 74(5): 140-158.

Yin, R.K. (2009), Case Study Research: Design and Methods, SAGE Publications, New Delhi, India. 